\title{
Wong Cilik in Javanese History and Culture, Indonesia
}

\author{
*WASINO ${ }^{1}$ \\ ENDAH SRI HARTATIK ${ }^{2}$ \\ FITRI AMALIA SHINTASIIWI ${ }^{3}$ \\ ${ }^{1}$ History Department, Faculty of Social Sciences, Universitas Negeri Semarang, \\ Semarang City, Central Java, Indonesia \\ ${ }^{2}$ History Department, Faculty of Humanities, Diponegoro University, Semarang City, \\ Central Java, Indonesia \\ ${ }^{3}$ Social Studies Education Program, Faculty of Social Sciences, Universitas Negeri Semarang, \\ Semarang City, Central Java, Indonesia \\ *Corresponding author: wasino@mail.unnes.ac.id
}

Published online: 29 October 2021

To cite this article: Wasino, Endah Sri Hartatik and Fitri Amalia Shintasiiwi. 2021. Wong cilik in Javanese history and culture, Indonesia. KEMANUSIAAN the Asian Journal of Humanities 28(2): 31-51. https://doi.org/10.21315/kajh2021.28.2.2

To link to this article: $\mathrm{https}: / /$ doi.org/10.21315/kajh2021.28.2.2

\begin{abstract}
In every country, regional social concepts are of significance in the political environment. In Indonesia, about $40 \%$ of the population are ethnic Javanese. Accordingly, their cultural concepts bear a considerable influence on the political map and presidential elections. As a large community, the Javanese hold on to longstanding historical notions of the position of the ruler and the wong cilik or commoner in the mechanics of governance and governmental administration. In Javanese social stratification, the ruler and the people are conceptualised and positioned in different ways compared with governance in modern democratic societies. Two broad social levels can be distinguished the wong cilik, consisting of peasants and the city lower classes, and the priyayi (or ruling elite and high class society). They can be somehow compared with the traditional classification of the proletariat or the working class and the bourgeois, the holders of the means of production. Both have their own social and economic life but have an interdependent relationship of exchanging services and goods. This relationship is known in Java as kawula and gusti, a cultural "patron-client" relation, containing supporting reciprocally based on authority.
\end{abstract}

Keywords and phrases: people, commoner, elite, power, patron-client relationship, harmony 


\section{Introduction}

In Javanese culture, wong cilik (common people/commoner) has an ambiguous meaning. Their social class is somehow cornered for unattractiveness in status and low economic progress, while on the other hand, it is defined as a high potential social class of voting power and the increase of political representation, depending on the eye of the beholder. An Indonesian maxim is used to define aspects of their economic social status; wong cilik lungguh dingklik mangane gogik, duwite setengik or the commoners sit on old wooden chairs, eating fake rice made from cassava and have little to spend. From a geographical aspect, the wong cilik mostly live in the countryside. This is far away from the glitter of the royal capital or kutha gara, the abode of the king and high-class society, also known as the priyayi. The socioeconomic distancing can be worded as adoh ratu cedhak watu or close to the throne far from the stone (Semedi 2003). The living of the commoners is usually set in a Javanese hamlet and life tightly integrated with nature while depending on what agricultural yield can be produced from the soil. If the hamlet is close to the coast, the people are mainly depending on what can be caught with their nets from the sea (Widyatmadja 2010). Their reality is challenging, as their socioeconomic position is captured at the bottom of a feudal Javanese cultural system (Kawangmani 2019; Holt 2007). Feudalism is a sociopolitical shackle that can deem the wong cilik throughout their life to suffer and condemns many to remain poor or badly nourished (Curtis 1997; Nugroho 2001). Although they are prevalent in the countryside, they also provide services in urban environments (Koentjaraningrat 1970, 140).

The commoners are noted to be lacking refined worldly knowledge or taste and are portrayed to be on the rough side of Javanese culture (Purwoko 2008). This is due to the presumed sophisticated culture that is dominated by the royal family and their inner-circle, reflection of high style civilisation (Anggraini 2018; Curtis 2002). Their sophisticated culture is an urbanised phenomenon radiating from the centre of power embedded in the sultan's palace. Living a distance from the capital can be considered to offer less refinement (Mulkhan 2004). Most of those in the Indonesian styled client-patron relationship are the rural peasants who live in village communities far away from the city. Hence, Thukul Arwana, a presenter of the Bukan Empat Mata television show raised the notion of the wong cilik, as being compartmentalised with antisocial elements who might also be encountered in the city. As less sociable and negative connotation of the wong cilik term has stigmatised a whole segment of the Javanese population (Santoso 1999; Mundayat 2005). Their identity was equalised to be living on the edge of poverty-stricken society (Kaligis 2014), be subject to suffering (Abdurrahman 1989) and be bursting of unresolved difficulties 
(Ridwan 2004) in an endless chain of misery. That is perhaps the image of wong cilik life in Java, being victims of the middle class and the elite's prejudice in society. On the other hand, the wong cilik as a social class has become an important group not to ignore when the political contestation of democracy is taken into consideration. Their voices and votes became vital and valuable (Scherer 1981; Kuntowijoyo 2003). They were seen as key vote bearers who could be supportive and of vested interests of the established powers (Jazuli 2003; Harris 1987).

Due to the significance of the wong cilik voting power several political parties focus on elements in their political campaigns that assist the wellbeing of this particular social stratum. Especially the Partai Demokrasi Indonesia Perjuangan (PDIP) or the Indonesian Struggle for Democracy Party embraced the term wong cilik to provide comfort to voters in rallies and political platforms. In almost every ideological campaign it encouraged a political struggle to improve conditions for the commoners. Similarly, the leaders of several other political parties appealed to the voting power of the commoners and focused their political parties' ideology to improve the long-forgotten wong cilik social position. As explained earlier, this political contestation never found a true purpose of change, as could be expected by the members of this class (Van Klinken 2008; Nordholt 2015). The excitement of being part of a political discussion lasted only for short awhile and only derived limited satisfaction (Allen 2015; Aspinall 2014). The limitations in the discussion are exploited and sold as a very attractive political marketing commodity that arouses interests in making choices available (Miñarro et al. 2016; Aspinall and Berenschot 2019). In Javanese pluralism, the life of a wong cilik citizen has never been given a place of honour other than in a shadow play of political contestation (Wasino 2013; Suharso, Setyowati and Utomo 2020; Suharso et al. 2020). They were mere objects of socioeconomic exploitation (Scott 1972; Powel 1970; Izzah 2016), or a political commodity to be taken advantage of (Fatgehipon 2018; Holt 2007; Muntholib 2008; Utomo and Kurniawan 2019). It is a fact that many cultural-political players who have fallen into misery, have their lives recorded in the Indonesian national history (Kurniawan et al. 2019). The values of modern humanity cannot touch them, as their social position has fallen to the bottom of the social structure. It remains a challenge to establish and rise as a new force in Indonesian politics and arrange for guidance in culture.

This research is to call attention to the social layer in society often referred to as the wong cilik and be critical through a historical and sociological analysis of their lives. The main object of this research is the historical aspect of the wong cilik in Javanese culture and its position when Javanese feudalism collapsed. 
The research is initiated by library research of historical data and clarification, with an understanding based on a new socio-historical interpretive analysis. Historical analysis is the key to discover the sociopolitical or sociocultural roots of the wong cilik social stratum formation and the historically limited respect in society. Poverty, suffering and losing are terminologies that will often be discussed, because the life of wong cilik in Java cannot be separated from these three aspects. The Javanese culture is being taken as a focal point as a large number of Javanese citizens could be classified as the wong cilik. Nevertheless, as a social group, they have been influential in determining political policy and even the national political leadership in Indonesia.

\section{Between the Wong Cilik and Kawula: A Theoretical Framework}

In the Javanese social stratification, there are two particular lower social level classifications, the kawula and the wong cilik. According to Kuntowijoyo (2003), they are near similar, as both groups are in the lower class of the social stratification. The higher social stratification is known as the priyayi or the elite in Java. The highest social stratification in Javanese society is the raja, sunan or king.

The wong cilik social stratum has two sub-levels, the wong cilik biasa and wong cilik saudagar (commoner-trader) (Kuntowijoyo 2003, 200-201). The simplification of kawula with wong cilik is not completely appropriate as Soemarsaid Moretono (1985) clarifies this by briefly explaining the concept of kawula which has a different meaning to wong cilik kawula. It means "servant" for both wong cilik and priyayi. Priyayi refers to the king's servant while wong cilik refers to priyayi's servant.

Wong cilik conceptually lives in the rural areas while priyayi lives in urban one. This is in line with a statement by Pujo Semedi (2003) earlier. The separation is truly related to culture adopted by social group of wong cilik which is different from the urban culture adopted by priyayi. Urban area is defined as the royal city or state city. It can be seen from their language, behaviour, house and the developed tradition. However, in reality, wong geographically can be live both in the rural and urban areas (Koentjaraningrat 1970, 139-140).

The meaning of wong cilik has emerged in the classic Indonesian history in the development of Hindu-Buddhism Kingdom era. Due to the historical influence of Hindu-Buddhism in Indonesia, the social stratification distinguished the priyayi (the noble) and the wong cilik. The original caste system theoretically contained four levels: brahmana, ksatria, wesia, sudra and other sub-castes named paria or jaba. The kstaria and brahmana were the upper cast in contrast with the 
lower castes. The relationship was illustrated as a cosmic relationship which was separated from earthly life. Capital city was the place for the brahmana and the ksatria, while the sudra lived in rural areas. The cosmic boundaries became flexible after the development of a business class who were traders of goods and professional services. The traders or banyaga in Sanskrit or dagang in Malay included travellers who were strictly forbidden to enter Sima (a free area for religious institution). Additionally, there were varied social groups in the community who had derived special right from the king. In the Hayam Wuruk era in $1350 \mathrm{CE}$, there were the guards who guided the crossings of the Brantas and Bengawan Solo rivers, the horse drawn coachmen, the blacksmith, the fishermen and other skilled persons with special rights (Lombard 2000a, 32). The lower social class in the rural areas included the wanua or thani child. They were rural dwellers who were employed in agriculture and social sector under the rama or supervisor who was appointed the leader of the wanua or village (Rahardjo 2011, 68).

In Indonesia, before modern history, commoners were divided into two groups; the free or meherdika and the non-free slave servants or hamba. The general stratification in communities in the sultanates located in Java or Sumatera showed a large number of common members who were free or non-free servants. A small number of aristocrats and gentry or priyayi were the wealthy and powerful (Fatgehipon 2018; Aspinall 2014). Among the wealthy members of society, they were the sultan and family with court advisers and chief officials. In that social stratum, there was a small group of people who complied to be well off and usually called rakyat or people of the society. However, this term was commonly used in the Indonesian texts of the 16th century. In a shift of language interpretation, the term rakyat was increasingly used as a reference to Indonesians connected to heroic deeds, noted in the early 20th century.

Among the common people, there was a socially disadvantaged group of poor called the fakir miskin. The word was derived from the Arabic language and was focused on people in need of sympathy from others, as they were less fortunate or unable to satisfy their primary needs. From a cultural perspective, the relationship between the sultan and his subjects was based on humanity. A king ought to be generous to his subjects. in this drift of thought, commoners did not perceive a sharp gap in the notion of bourgeois and proletariat. It was more of a symbiotic relationship where the wealthy extended care to the needy or served the unable people in society.

There were two ways of how a free person could become a slave or hamba. Firstly, they could become slave servants as they were captured and evacuated 
as a result of war loot or raid. Secondly, as a free person, they had accumulated debt which they were unable to pay back. In exchange, until they had paid their so-called debt, they were deemed to be a slave servant (Lombard 2000a, 169-170). This practice which treated commoners as hamba, was exploitation overshadowed by colonial rule. For Sukarno, a freedom fighter and the first president of the Indonesian nation, this practice was rightly perceived human exploitation that enriched the masters in colonial countries. From a sociohistorical perspective, this behaviour could be explained as the Dutch continued to enrich themselves as explorers. At the same time, the occupied communities were locked down with restrictions and at times with torment. In particular, the wong cilik became victims in those socioeconomic relations (Suhartono 2000; Mundayat 2005; Kuswono 2016). The hindrance of being the underclass did not stop when Indonesia had achieved independence on 17 August 1945. The practice of totalitarian behaviour continued by the newly formed Indonesian elite and middle class in a system of contemporary capitalism. The reality was that the increased industrialisation had created factories in dire needs of a low skilled labour force. The elite's domination of the wong cilik is even more complex and continued to undergo an evolution that did not necessarily require merely forces of labour.

The term wong cilik has strengthened to become a regular term in Indonesia in the 20th century. In 1926, Sukarno established the Indonesian National Party (PNI) with a focus on the masses in Indonesia (Izzah 2016; Kaligis 2014). That term could be aligned with a proletary concept in the Marxian theory, although not identical. One of the most important elements of the social groups are the peasants. They are both the owners of labours and the capital owner from a repertoire of production relation. This was in contrast with the working class in Europe in the 19th century, which was like a capitalist production machine that was only providing labour without capital (letar) (Komarudin 2016; Nugroho 2001; Santosa 1999). In the effort to escape from the shackles of colonialism, the wong cilik became an agitative discourse and turned to be a force for the left-wing nationalist or Islamic-led groups pioneered by the Indonesian Communist Party (PKI) or the PNI. Those were at that colonial time the political parties in full struggle for Indonesian nationalism and autonomy (Shiraisi 1990; Van Klinken 2008). Islam had been one of the identities and was always identical with wong cilik in Java, although they mostly followed the abangan affiliation or Islam fused with Javanese cultural practices (Yang and Samsudin 2017; Bensaid and Tekke 2018). Islam in Java is quite dominant with communal mass meetings and whose majority is poor and suffer (Mohd Noh, W. Mohd Azam and Majdan 2019). 
The wong cilik in Sukarno's (1983, 129-139) thought was indicated as the marhen or kromo. The kromo people are communities of poor peasants, labourers, small traders and sailors. Marhaeinism and kromoism were believed to be part of the Indonesian society during Dutch colonial times. The kromo community was swept up and encouraged to agitate against the imperial system as it had oppressed society (Yang and Samsudin 2017; Sukarno 1983; Suhartono 2000). At the beginning of the 20th century, colonialism and imperialism were objects, mostly opposed by young activists and politicians from the priyayi middle-class who used the wong cilik as a basis to oppose the ruling class. Sukarno himself, although he came from Javanese aristocracy, let go of all his noble attributes to melt into the wong cilik class and oppose, to instigate independence for the Indonesian people (Suseno 2001; Mudayat 2005). The trait was also known as egalitarianism which at that time appealed to the educated people in Indonesia.

The term kromo is used to identify the lower stratum in society, as that name was commonly used by people living in rural areas. Even there was a story of a villain named Kromo Leyo. On the other hand, no one in the priyayi stratum used that name. Shortly afterwards, the term kromo became a synonym for the common people (Moertono 1985). Kromo was also identified as a noun for oppressed people who were shackled by poverty and lacked broad access to the political bureaucracy. They were also people who during colonial times were near slaves with limited human dignity. When war was declared by the state, they stood in the front lines to become the shields for the elite. When the state was experiencing a crisis, they were the people who were sacrificed. The people belonging to the kromo community in the national movement were a progressive element to build communalism in the struggle against European colonialism for activists such as Sukarno (Nordholt 2015; Rahardjo 2011). Kromo is an important element in the discourse and in need to be continually discussed for the life of politics. This is the historical root of the kromo community or wong cilik to become a valuable political commodity and a challenge to measure with other social classes.

Indeed, Sukarno was a prominent figure who struggled for the underprivileged in Indonesia. It is said that one day he was walking around the field in the village and met a farmer named Marhen. His life was very wholesome, but far below adequate while living in a sugarcane plantation belonging to a Dutch planter. Sukarno asked Marhen about the ownership status of the field and he answered that the field belonged to him. Sukarno concluded from his observations that Indonesian peasants could not be equated with the Western notion of proletarians who do not have sufficient capital or means of production (Yang and Samsudin 2017). It was deducted, that the Indonesian peasant ought to live prosperously 
as they were the owners of the production factors including land and labour. The investment factor of foreign capital combined with colonial greed caused those in the field to remain poor. Based on his experience, Sukarno delivered a speech, raising the spirit of the people and to strife for independence.

\section{The Commoner in the Case of the Mataram Islam's Bureaucracy}

In the mystical tradition of Javanese power, the king is the centre of supreme power. As the sultan has been endowed with the Arabic honorific title Kalifatullah Sayidin Panata Gama, it implies the sultan represents God on earth. For preserving the traditions in state ceremonies, the sultan was assisted by the state civil servant corps (abdi dalem). Hence, the concept of abdi (servant) had a structural change and solicits a shift in meaning when compared with the earlier development of Islam which implied the meaning of hamba. Beyond these circumstances, there are social groups in society known as the commoners wong cilik, the state civil servant corps (abdi dalem) and the royal family referred to as a priyayi. This phrase comes from the word para yayi (yayi or rayi meant brother, the king's brothers). In mangkunagaran (a principality in Surakarta, Central Java), this social group was known as nara praja (Wasino 2008). The civil servants had the role of liaison between the people and the king. The priyayi were the immediate servants of the king. They were distinguished from the wong cilik or other common people because they enjoyed in the civil servant corps employment without the need to exert employment on their own farm (Onghokham in Tjondronegoro and Wiradi 1984, 6).

According to tradition, the followers of the Mataram Islam were divided into two groups, the priyayi and wong cilik (Kartodirdjo 1987, 3). The king, and his relatives were part of the priyayi in society. The priyayi was also used in reference to high ranking government officials. They were both working for the sunan, sultan, mangkunagaran and the officials of the colonial government. In fact, in Surakarta citizens who were employed in the government had a close lineage or affinity with the royal family. It can be noted from the personal title bestowed on them such as Kanjeng Raden Tumenggung (KRT), Raden Mas, Raden Ayu (Raden Ajeng), Raden Rara and Mas. Those honorific titles indicated their privileged social status in society. The title of KRT was bestowed to the highest elevated officials indicating their close relation to the king. Low-status officials have bestowed the title of Raden, or Mas. Additionally, there was a group of professionals, employed by the colonial government with skills such as doctors, engineers, teachers who were brought into the aristocratic realm (Scherer 1985). 
Although the wong cilik in the Javanese cultural jargon had a degrading connotation, their presence was needed. The panggede or rulers would be useless without having commoners to command. The Javanese culture illustrated their relationship as the sesotya lan embanan or "between the ring and its frame". In modern times, this relationship is getting more complicated as there is a pragmatic element in the current practice of capitalism in rural areas (Komarudin 2016; Siregar 1998). The wong cilik as a group is an economic force, whose energy is needed to run the wheels of industry (Anderson 1974). The current average commoner's life still has shortcomings to prevent it from calling a decent prosperous life (Hastuti 2011). The kind of industrial lifestyle of the wong cilik is perhaps a still a social platform for extortion and exploitation of human resources (Kuswono 2016). The large numbers and their desire to climb out from their traditional role serves them with new problems (Wasino, Hartatik and Nawiyanto 2019; Jayusman, Wasino and Suyahmo 2020).

The wong cilik is a reference to common people and include farmers, handymen, traders, craftsmen, street artists, etc. If the priyayi had a particular honorific title bestowed on them, the wong cilik do not have a claim to such provision. The Javanese used to refer to them as kawula or servants and represents human suffering and poverty. They are the living witnesses of the historical development of nations and people who are trying to free themselves from poverty and shackles of capitalism. The institutionalisation of capitalism has made it more difficult to carry out social mobility (Aspinall and Berenschot 2019). They always have lived in the shadow of the elite, both political and from an economic perspective and are needed to fulfil the elites' interests. Indeed, with such severe consequences that the wong cilik are marginalised people without strong networks.

According to Suhartono (1991, 33), those two main social stratifications have different cultural concepts and they have been shown in the apanage structure. This is not only reflected in how they are being addressed. The priyayi have dissimilar routine and lives compared with the wong cilik communities in society. It is covering housing, clothing, food, speech, manners, education and other social symbols that are typical in the circles of the different classes. Linguistically, the social layers have separate vocabularies in the Javanese language. It is spoken by the different classes and referred to as the low and high-class language. The priyayi use the language that is associated with a polished word choice while the wong cilik use a separate unpolished Javanese language. Contrasting the two groups, there is a Javanese proverb illustrating it: Dupak bujang, semu mantri esem bupati (Moertono 1985). Bujang refers to the low-class peasants who only work for their boss and did not have their own field. Their employment only assisted 
the sikep, a farmer who owned the field and is closely affiliated with unrefined manners. Meanwhile, the low governmental officials' mannerism was described as rather polite. If they warned other people, they only satirised (pasemon) them and priyayi (the nobles) received the message of their social standing. The highest priyayi affiliated, such as the governor, would have politer behaviour and would warn other people merely with a smile.

The priyayi class became a role model for their people and desirable for every person to follow. Peasants as their servants obeyed the nobles who were above their social class. They include the demang, mantri and penewu. Due to the high social values of the priyayi, people desperately desired to be included in this social stratum. In the early 20th century through schooling, higher education and by extensive dedication to their tasks (nyuwita) to priyayi, they were able to lift their status (Kayam 1992). The priyayi social stratum was divided into two substrata; the priyayi luhur and the priyayi andap. Priyayi luhur was the upper group of priyayi, and the wedana was their superior. On the other hand, the priyayi andap consisted of low-level officials such as the village headmen, orderly, rural teachers and others.

In the mid-19th century, together with the development of the colonial and plantation bureaucracy, the bureaucrats strengthened their status by supporting the implementation of the colonial administration (Scherer 1981; Abdurrahman 1989). Many positions in the colonial administration were fulfilled by lowclass officials such as clerks, tax collectors, cashiers and their supervisors called the orderly. There were leaders from the peasant community of the low level bureaucracy, called the bekel. From the aristocrats' perspective, the bekel was not included in the social strata of the priyayi. Nevertheless, in the peasant community, the bekel officials were considered part of the priyayi with almost aristocratic respect extended to those officials. Even some powerful identities from that group were considered as marginal kings in the remote rural regions. Before the agrarian re-organisation, this particular powerful group held the key to arrange the flow of tax supply to the government and the provision of labour for both feudal and customary purposes.

Most of the wong cilik were peasants working on their fields and not considered landowners according to Javanese land holding concepts. The ultimate landowner was the king who loaned land through an intermediate to their extended family who in turn arranged peasants to plant crops. The farmers merely have tenure rights (anggadhuh). The peasants were divided into several social classes based on their land tenure. Their control of the land could be seen from the names given to the land, especially heirloom land and self-developed land. 
According to the Jaarlijk Verslag (annual report) of 1852, the villagers were divided into four social strata. The highest social class was the sikep or kuli kenceng. They were the people who controlled the land, were taxpayers, worked and obeyed the king. Bekel and other low-class officials came from these social strata. Secondly, under the kuli kenceng class was the kuli setengah kenceng or kuli kendho class, or farmers waited for their turn to work the land. Thirdly, the kuli indhung or kuli tlosor social-class below the previous class. They were the people who did not pay taxes but supplied their labour to the kuli kenceng class and responsible for their food and dwellings (Suhartono 1991, 34; Wasino 2006, 25-27). The term of kuli initially is used to refer blue-collar worker working in factory and then is adopted to peasant (Boomgaard 1989, Part 2, Chapter 7).

Being priyayi traditionally is due to heredity. The noblemen will be priyayi. However, since the early 20th century, new priyayi emerged. They studied from the western education institution who worked in the Dutch Colonial Bureaucracy Institution. Thus, social mobility from wong cilik to be priyayi was opened. First, they traditionally encouraged their children to give birth to priyayi generation through marriage. Secondly, they sent their children to European formal schools.

\section{The Social Relationship between Wong Cilik and Panggedhe}

The relationship between the wong cilik and the elite in the Javanese tradition is bounded by religious ideology. The relationship was known as the kawula-gusti (the patron-client) relationship. In the pre-Islamic era, the God-king ideology became the basic conquer of the wong cilik class by the rulers and in the Islamic era by the united social classes or manunggaling kawula-gusti (Onghokham 1983, 94). Theoretically, the relationship between the ruler and the people was harmonious. Based on modern terms, the relationship could be interpreted as "patron-client" harmonious. The subordinating farmers were the basic political and act as their military force for the priyayi (Tjondronegoro and Wiradi 1984, 10).

The relationship between the commoners and the sultan was not rational or contractual but was a personal, warm and respectful mutual symbiotic. Ideally, it had care similar to parents and their offspring. The inward and mystical alliance depicted the ultimate purpose of human life that was achieving the true union manunggaling with God. Both had a significant hierarchy, but be united because of their similar characteristics. Even though there was a unifying bond, they had an official dividing line from the social hierarchy of the patronclient relation which could not be disobeyed. The patron should think like a 
master and the clients had to behave like a servant. The violation of these rules could disrupt the cosmic balance. By accepting their existence, good social communication between both groups would be achieved (Moertono 1985, 17-19). The mangunggaling kawula-gusti concept was inspired by an Islamic mystical concept which became the Al Ghazali guide ihya ulum addiin. This concept continuously became the Sufis' guide across Indonesia and it exists till now.

Kawula-gusti concept was marked with another characteristic from the Javanese belief, namely fate or destiny. Someone was destined becoming a client or a patron due to his fate. Furthermore, based on the Javanese terminology, it was stated as pinesthi (determined) and tinitah (destined). The separation in the social strata between wong cilik and panggede (the rulers), was not primarily based on wealth or birth, but this was from the aspect of kawula (clients) to bendara (patron) and someone's position in the society. Their rights and duties were deemed as fate (Moertono 1985, 19).

Initially, the patron-client relationship was harmonious because the people and the rulers trusted each other. However, this relationship started to be tenuous when the territory areas belonging to the Javanese rulers including Surakarta started to be exploited by European capitalism. The basic relationship was no longer based on gemeinschaft (community), but gesellschaft (company). The capitalistic production relationship had spread the heart of Javanese culture since the early 19th century and grew rapidly in the early 20th century. Related to the capitalisation process of the heart of Javanese culture, Takashi Shiraishi (1990) divided the stages of human development in Surakarta into three mayor centuries. It was triggered by the Liberal Colonial Policy and private capitalism in 1870 when the colonial agrarian law was standardised and the colonial railway tracks were laid in Surakarta. The Semarang-Surakarta line was sponsored by a private train operator called Nederlandsch Indische Spoorweg Maatschappij (NISM). It was used to transport the sugar production in the Javanese sultanates or vorstenlanden (Shiraishi, 1990).

In the first part of the 19th century, sugar and tobacco were the main crops in Surakarta. Most of the land that originally belonged to the king and the aristocracy had been leased to the foreign private operators (Houben 1994). Thus, the direct relationship between the ruler and his subjects vanished. The deployment of foreign capital to the sultanates, including Surakarta, had segregated the spiritual relationship between priyayi and wong cilik. Traditionally, the relationship between the Mataram government and their people was not the governance of a particular land area. The governance was on a community, a group of subjects, underpinning the traditional economy 
(Shiraishi 1990, 12-13). Furthermore, the employment of European capitalism had damaged the traditional Javanese king and subjects and their fine-tuned patron-client relationship. In the newly formed agrarian plantation culture, the wong cilik had a new patron, namely the European capitalist, based on a rational capital relationship. As a result, the so-called clients had lost their traditional patrons. They expressed their dissatisfaction through new ways.

The second factor was related to the input of capital outside the agriculture sector, especially in the batik weaving and production. In the 1850 s, there was a significant change in the textile industry. In Semarang a new method was introduced by Kauman around 1840. The second stage of European capital expansion occurred in the 1870s. The expansion was not limited to the plantation sector and batik weaving but in transportation. The widening of the railway track and development of a line to Solo influenced the reach of new markets. In the early 20th century, Batik Solo became the main centre of the batik industry in Java. Several places became stone producers, such as Kauman, Pasar Kliwon and Keprabon, and Laweyan (Shiraishi 1990, 24-25). The development of the batik industry had initiated the new production relation and the new wong cilik worked not in the fields but indoor factories. Their loyalty was not for the old aristocrats but their new masters of the factory. This loyalty was based on a contractual industrial relationship.

The change in Solo, also known as Surakarta, is seen as the beginning of the modern century in Java. It was introduced by a new colonial policy called the ethical policy. New concepts appeared and related to the "progress" of the common people. Many people from Solo received an opportunity to obtain education and it triggered a new awareness of their society. The old wong cilik concept interpreted only as "a servant" was not any more commonly accepted. The birth of urban proletarians who worked as plantation or batik workers and small traders was concerned with social class and opposed injustice as a result of introduced European capitalism, migrants from the north and Javanese feudal rulers in Surakarta (Shiraishi 1990, 27). Suhartono (2000) argued that the introduction of European plantation capitalism in the sultans' domain had replaced the Javanese nobles' position in exploiting their people. The farmers were assumed to be subjects who had to work hard to trigger the capitalist introduced machine at a very low reward.

Furthermore, Suhartono assumed that the farmers still had optimism even though they were under the pressure of European capitalism. The peasants' ethics taught them they were destined to serve the rulers. When the power was diverted from the Javanese aristocracy to the private plantations, they were also subservient 
and obedient and they lived with this optimism. This perspective lasted from 1850 to 1940 . They faced their future with hope and several proverbs appeared to calm their mind. For instance, the Javanese proverb ono dino ono upa (ada hari ada nasi) or with rice every day, there is life. With a continued hope for the birth of the wise king, they continued their life as titah wong cilik as nromo ing pandum (menerima pemberian Tuhan) or receiving the gifts from God (Suhartono 2000, 261-262).

Indeed, those concepts showed that peasants or wong cilik struggled with a changing system. However, their opposition was not open, but they did secretly as they had less power while waiting for the appearance of the wise king. The new offer of "the wise king" emerged, such as in the development of Sarikat Islam under Tjokro Aminoto's lead. With the left Islamic movement under Haji Misbach's lead, the peasants and the factory workers acquired a new medium to express their aspirations (Larson 1990).

After the patron-client relationship faded and priyayi could not protect their subjects, the people chose a different political path from their masters away from the aristocracy or priyayi. Even in the political New Order period of Suharto, there was a political path based on social class and culture orientation. Geertz (1981) divided the Javanese people based on their cultural orientation and identified them into three variants namely the abangan, santri and priyayi. Most of the wong cilik identified themselves as abangan, with an orientation to the PKI. While the santri tended to orientate to the Islamic party such as Nahdatul Ulama Party in the rural and Masyumi in the urban areas. On the other hand, the aristocratic priyayi had a politic orientation to the PNI (Geertz 1981).

During the Reformation, the power of the wong cilik changed. Their political orientation became more varied. However, the PDIP drew the most benefit because this party openly supported the voice of the wong cilik at the end of President Suharto's reign and the beginning of the reformation. The PDIP became a medium for expressing people's aspiration to struggle against the New Order rulers in the Suharto era, identified by Golongan Karya political party. Golongan Karya lost their votes either in the rural or urban areas due to the strength of PDIP. This political party always represents itself as a party of wong cilik, who fought for their rights in the constitution. However, this phenomenon turns to be unclear as new political contestations took place in Indonesia (Kuntowijoyo 2003; Kartodirdjo 1987). Although political dynamics are always change the platform, the strength of the PDIP was now getting stronger due to the support of the wong cilik in the form of convincing campaigns and taglines. 
The sympathy of the wong cilik continues to flow to the PDIP and make it the ruling political party during the two periods of leadership in Indonesia from 2014 until 2019 and 2019 until 2024.

Many political parties in Indonesia claim to pay their attention to the wong cilik nowadays. Due to their numbers, they were contested by several political influences, especially after Megawati failed to fight for their aspirations. This was with many corruption cases exposed in the government sector involving many regional heads from the PDIP. As a result of this, many political parties claimed themselves as reformation parties including Golkar who fight for wong cilik prosperity. This was followed by the transactional politics between the political parties and the people. Most of the political orientation by the people became more pragmatic by accepting cash or aid. This would be allocated for building infrastructure in their neighbourhood such as roads, mosques, public water facilities and other public works.

\section{Punakawan Figure as Another Side of the Wong Cilik}

The Javanese culture places the wong cilik stratum at the lowest social hierarchy. Fortunately, they became an important element in the society for the priyayi. This is colourfully reflected in the Indonesian wayang puppet play, in which common people were represented as the punakawan. In the dialogue of the show, either the priyayi Amarta or Astina always asked for pieces of advice from their commoners if they encountered problems (Ridwan 2004; Onghokham 1983). Punakawan in Amarta or Pandawa were servants who had the Javanese etymology; jarwa dasak "pangembating tutur" or "pangembating atur" which means a place asking for advice. In many puppetry plays, the priyayi, are emotionally close to the wong cilik and take care of them (punakawan), resulting in the successful management of their domains.

The puppetry plays might imply the voices of the wong cilik were God's voice the priyayi should take care of. Accordingly, the leader of punakawan in the Pandawa family was Semar. Semar and his sons (Gareng, Petruk and Bagong) appeared at midnight, known as gara-gara. The rise of gara-gara giving a reflection in a critical situation in the human world or Arcapada. Their critical situations include natural disasters such as volcanic eruption, flash floods, earthquake and other events.

Suseno $(2001,186-187)$ stated that the task of Semar and his sons was to escort the main knight in overcoming the dangers in each play, reflected in the incident of gara-gara. If the knights had troubles, Semar provided advise. If they were 
too emotional or aggressive, Semar carried out alternative solutions. Besides, if the knights looked sad, the punakawan treated them with jokes, if the principle knights were lonely, the punakawan accompanied them. Moreover, punakawan come to the rescued if they were in troubles. The legend of punakawan is intimately related to the aspects in Javanese culture. It is one of the most influential mythologies related to Javanese leadership and a way of Javanese life and society. The legend contains messages about simplicity, accepting destiny and always being thankful for the life given by God (Suhartono 2000). Semar was considered to be the incarnation of a benevolent deity and in favour of the wong cilik. He was also portrayed as a faithful bodyguard, therefore many parents in Java are always keen for their children to imitate Semar, who acts with good behaviour and gives intelligent advice.

Punakawan was a true wong cilik as knights. In Javanese, they were called sang pamomong, ngemong, meaning "supervising, to keep their masters safe". Interestingly, although the main knights belonged to a high social stratum, they spoke to Semar in krama inggil, which is the highest variation of the Javanese language. This might teach Javanese leaders to be respectful to wong cilik as their existence was necessary for the priyayi's safety (Lombard 2000b; Kuswono 2016; Kayam 1992). As a result of their caring, Pandawa always won the wars, due to the performance and intelligence of Semar. In all plays, Semar is the most beloved character of the audience despite his unattractive appearance. This is perhaps due to him always defending the truth and it was the knights who fought for truth and justice. Almost in all performances, Semar was never wrong and he was always invincible. He even acted as the last person to declare victory when the knights were not able to beat the villains.

Semar was a representation of the wong cilik and in many stories, he was called $\mathrm{Ki}$ or Kyai Badranaya who was not an ordinary wong cilik. Moreover, he was represented by a wong cilik character, but his origin was not an ordinary person. He was a god known as Sang Hyang Ismaya (Izzah 2016; Harris 1987). He was prestigious more than any other gods including the principal god, Bathara Guru. Semar uttered in ngoko, the lowest level of the Javanese language, to Bathara Guru. He also braved to criticise the intelligence in his head, if he was mistaken in setting policies for the universe and humanity. His critics were straightforward, tanpa teding aling aling (in Javanese), which showed the God's language transformed into the language used by wong cilik.

Geertz $(1981,264)$ argued that the existence of Semar and his sons embodied the relativity of the aristocratic goals about a cultured and kind-hearted knight reflected in Arjuna, the second knight of Pandavas from Amarta's Kingdom. 
Based on Javanese concept, if a person had a gentle appearance, he would have a gentle heart as well. In contrast, if a person had a rude appearance, he would have an impolite behaviour too. Thus, those assumptions were irrelevant because this condition did not correspond with the figure of Semar. Due to the importance of Semar in the nobles' life, the Javanese nobles wanted to be close to him. Unfortunately, many of them conceived the literal meaning, so many nobles had Kyai Semar Kris as sipat kandel that was to raise their position. However, this actually should be implied that if they would like to raise their position, they had to be close with Semar as the representation of people. Loving Semar meant loving people. Despite they were rude, their voices sounded like gold. Therefore, in this concept, democratic values have become a significant part of Javanese culture.

\section{Conclusion}

In Indonesia, the Javanese historical-social stratification has been influential in politics. The position of the common people or wong cilik has been two-fold. They were historically providing labour and tribute to the ruling class or the priyayi and on the other hand, were expected to rescue the ruling class from unstable situations to maintain power in certain situation.

The wong cilik social class emerged following a succession of external cultural influences that introduced social stratification and bureaucracy. They became a social group following the pattern of the social and cultural changes at the bureaucratic level. When patrimonial bureaucracy ethically protected them, the wong cilik was subservient and obedient to the rulers. However, when the social changes were caused by the European capitalist investment which had a consequence in the disappearance of their traditional patrons, the wong cilik found their own way to survive. Furthermore, the rebellion against their traditional elites occurred.

Javanese culture taught the balance of the harmonious cosmic relationship between the wong cilik or clients and their patrons. In certain situation, the wong cilik or the commoner's, voice might be heard to preserve the rulers' power. Furthermore, the rulers should also remember that they obtained their position due to the people's struggle. If the political-cultural concept was kept preserved by both social groups, in an instant Indonesia would be a great country.

Reflected from the wayang puppet play, Indonesian governments should take their lessons. Supposing the executives and judicial powers were equated with the knights' caste that was the people who controlled government and justice, 
thus the People's Representatives Council might identify themselves as punakawan, especially Semar as the representation of the people. Therefore, they became the representation of the wong cilik who might give proper advises to the government and the court for an Indonesian victory.

\section{References}

Abdurrahman, M. 1989. Wong cilik dan kebutuhan teologi transformatif. In Teologi pembangunan: Paradigma baru pemikiran Islam, ed. M.M. Amin, 153-161. Yogyakarta: LKPSM.

Allen, N.W. 2015. Clientelism and the personal vote in Indonesia. Electoral Studies 37: 73-85.

Anderson, B. 1974. Revolution and social tensions in Surakarta 1945-1950. Indonesia 17: $99-111$.

Anggraini, D.A. 2018. Penggambaran kehidupan petani tembakau sebagai wong cilik dalam novel "Genduk" karya Sundari Mardjuki (sebuah tinjauan antropologi sastra). PhD diss., University of Muhammadiyah Malang.

Aspinall, E. 2014. When brokers betray: Clientelism, social networks, and electoral politics in Indonesia. Critical Asian Studies 46(4): 545-570.

Aspinall, E. and Berenschot, W. 2019. Democracy for sale: Elections, clientelism, and the state in Indonesia. Ithaca, NY: Cornell University Press.

Bensaid, B. and Tekke, M. 2018. Islam and prejudice: Special reference to Gordon W. Allport's contact hypothesis. KEMANUSIAAN the Asian Journal of Humanities 25(Supp. 1): 103-120. https://doi.org/10.21315/kajh2018.25.s1.6

Boomgaard, P. 1989. Anak jajahan Belanda: Sejarah sosial dan ekonomi jawa 1795-1880. Jakarta: Djambatan.

Curtis, R. 2002. The wong cilik audience and the dhalang entrepreneur. In Puppet theater in contemporary Indonesia: New approaches to performance events, ed. J. Mrázek, 136-152. Ann Arbor, MI: University of Michigan Center for South East Asian Studies.

Curtis, R.A. 1997. People, poets, puppets: Popular performance and the wong cilik in contemporary Java. PhD diss., Curtin University.

Fatgehipon, A.H. 2018. The Javanese culture and Indonesian civilian-military relations in the era of Soeharto. TAWARIKH 9(2): 177-184.

Geertz, C. 1981. Abangan, santri, dan priyayi dalam masyarakat Jawa. Jakarta: Pustaka Jaya.

Harris, M.S. 1987. Doktrin wong cilik (pergulatan Islam dalam realitas). Yogyakarta: Azzura.

Hastuti, D.L. 2011. Status dan identitas sosial saudagar batik Laweyan dalam interior dalem indis di awal abad ke-20. Dewa Ruci: Jurnal Pengkajian dan Penciptaan Seni 7(1).

Holt, C., ed. 2007. Culture and politics in Indonesia. Sheffield, UK: Equinox Publishing. Houben, V.J.H. 1994. Kraton and kumpeni Surakarta and Yogyakarta 1830-1870. Leiden: KITLV. 
Izzah, L. 2016. Feudal culture in the Ijen highlands' poor society. KARSA: Journal of Social and Islamic Culture 24(2): 173-185.

Jayusman, Wasino and Suyahmo. 2020. Chinese in Lasem: The struggle for identity and living space. IOP Conference Series: Earth and Environmental Science 485: 012056. http://dx.doi.org/10.1088/1755-1315/485/1/012056

Jazuli, M. 2003. Dalang, negara, masyarakat: Sosiologi pedalangan. Semarang, Indonesia: Limpad.

Kaligis, R.A.W. 2014. Marhaen dan wong cilik: Membedah wacana dan praktik nasionalisme bagi rakyat kecil dari PNI sampai PDI-Perjuangan. Tangerang, Indonesia: Marjin Kiri.

Kartodirdjo, S. 1987. Perkembangan peradaban priyayi. Yogyakarta: Gadjah Mada University.

Kawangmani, S. 2019. Pola apologetika kontekstual untuk memberitakan kabar baik kepada suku Jawa wong cilik. Jurnal Gamaliel: Teologi Praktika 1(2): 59-71. https://doi.org/10.38052/gamaliel.v1i2.40

Kayam, U. 1992. Para priyayi: Sebuah novel. Jakarta: Grafiti Pers.

Keontjaraningrat. 1970. Masjarakat desa di Indonesia masa kini. Jakarta: Universitas Indonesia.

Komarudin, U. 2016. Ideologi partai politik, antara kepentingan partai dan wong cilik. Jakarta: RMBooks.

Kuntowijoyo, K. 2003. Lari dari kenyataan: Raja, priyayi, dan wong cilik biasa di Kasunanan Surakarta, 1900-1915. Humaniora 15(2): 200-211.

Kurniawan, G.F., Warto, W. and Sutimin, L.A. 2019. Dominasi orang-orang besar dalam sejarah Indonesia: Kritik politik historiografi dan politik ingatan. Jurnal Sejarah Citra Lekha, 4(1): 36-52.

Kuswono, K. 2016. Marhaenism: Social ideology create by Sukarno. HISTORIA: Jurnal Program Studi Pendidikan Sejarah 4(2): 119-130.

Larson, G.D. 1990. Masa menjelang revolusi: Kraton dan kehidupan politik di Surakarta 1912-1942. Yogyakarta: Gadjah Mada University Press.

Lombard, D. 2000a. Nusa Jawa: Silang budaya. 3rd Ed. Jakarta: Gramedia. 2000b. Nusa Jawa: Silang budaya. 2nd Ed. Jakarta: Gramedia.

Miñarro, S., Forero, G.N., Reuter, H. and van Putten, I.E. 2016. The role of patronclient relations on the fishing behaviour of artisanal fishermen in the Spermonde Archipelago (Indonesia). Marine Policy 69: 73-83.

Moertono, S. 1985. Negara dan usaha bina negara di Jawa masa lampau: Studi tentang masa Mataram II, Abad XVI sampai XIX. Jakarta: Yayasan Obor Indonesia.

Mohd Noh Abdul Jalil, W. Mohd Azam Mohd Amin and Majdan Alias. 2019. Politicocultural-religious milieu of South East Asia: An examination of pre-Islamic structures of authority and syncretic practices. KEMANUSIAAN the Asian Journal of Humanities 26(Supp. 1): 109-129. https://doi.org/10.21315/kajh2019.26.s1.6

Mulkhan, A.M. 2004. Makrifat Siti Jenar: Teologi pinggiran dalam kehidupan wong cilik. Jakarta: Grafindo Khazanah Ilmu.

Mundayat, A.A. 2005. Ritual and politics in New Order Indonesia: A study of discourse and counter-discourse in Indonesia. PhD diss., Swinburne University of Technology. 
Muntholib, A. 2008. Melacak akar rasialisme di Indonesia dalam perspektif historis. Forum Ilmu Sosial 35(2): 104-112.

Nordholt, H.S. 2015. From contest state to patronage democracy: The longue durée of clientelism in Indonesia. In Environment, trade and society in Southeast Asia: A longue durée perspective, eds. D. Henley and H.S. Nordholt, 166-180. Leiden/Boston: Brill. https://doi.org/10.1163/9789004288058_012

Nugroho, G. 2001. Resistensi wong cilik atas pasar (alokasi-konsumsi). Jurnal Ilmu Sosial dan Ilmu Politik 5(1): 91-119.

Onghokham. 1983. Rakyat dan negara. Jakarta: Sinar Harapan.

Powell, J.D. 1970. Peasant society and clientelist politics. The American Political Science Review 64(2): 411-425.

Purwoko, H. 2008. Wacana komunikasi: Etiket dan norma wong-cilik abangan di Jawa. Jakarta: Indeks.

Rahardjo, S. 2011. Peradaban Jawa dari Mataram Kuno sampai Majapahit Akhir. Jakarta: Komunitas Bambu.

Ridwan, N.K. 2004. Agama borjuis: Kritik atas nalar Islam murni. Yogyakarta: Ar-Ruzz.

Santosa, I.B. 1999. Profesi wong cilik: Spiritualisme pekerja tradisional di Jawa. Jakarta: Yayasan Untuk Indonesia.

Scherer, S.P. 1981. From culture to politics: The writings of Pramoedya A. Toer, 1950-1965. PhD diss., Australian National University. https://doi.org/10.25911/ 5d7239ca593a5

1985. Keselarasan dan kejanggalan: Pemikiran-pemikiran priyayi nasionalisme Jawa awal abad XX. Jakarta: Sinar Harapan.

Scott, J.C. 1972. Patron-client politics and political change in Southeast Asia. The American Political Science Review 66(1): 91-113.

Semedi, P. 2003. Close to the stone far from the stone: The story of a Javanese fishing community, 1820s-1990s. Yogyakarta: Benang Merah.

Shiraishi, T. 1990. An age in motion: Popular radicalism in Java, 1912-1916. Ithaca, NY: Cornell University Press.

Siregar, E.M. 1998. Harmoko sang otodidak milik wong cilik. Jakarta: Yayasan Mari Belajar.

Suharso, R., Wasino, Setyowati, D.L. and Utomo, C.B. 2020. Teaching multiculturalism based on Islamic historical relics in northern Java. International Journal of Innovation, Creativity and Change 11(10): 445-463.

2020. Cultural acculturation values in the Minaret of Kudus to foster harmony through social studies education. Paper presented at the 5th International Conference on Science, Education and Technology (ISET 2019), Semarang, Central Java, Indonesia, 29 June.

Suhartono. 2000. Konsep optimisme orang Jawa dalam ketidakpastian: Kehidupan desa di berbagai kerajaan. In Sejarah ekonomi modern Indonesia berbagai tantangan baru, ed. J.T. Lindblad, 259-280. Jakarta: LP3ES.

1991. Apanage dan bekel: Perubahan sosial di pedesaan Surakarta (18301920). Yogyakarta: Tiara Wacana.

Sukarno. 1983. Indonesia menggugat. Jakarta: Inti Idayu Press. 
Suseno, F.S. 2001. Etika Jawa: Sebuah analisa falsafati tentang kebijakan hidup Jawa. Jakarta: Gramedia.

Tjondronegoro, S.M.P. and Wiradi, G. 1984. Dua abad penguasaan tanah: pola penguasaan tanah pertanian di Jawa dari masa ke masa. Jakarta: Gramedia.

Utomo, C.B. and Kurniawan, G.F. 2019. Social wisdom of rural Semarang under capitalism. Paper presented at the 1st International Conference on Environment and Sustainability Issues (ICESI 2019), Semarang, Central Java, Indonesia, 18-19 July.

Van Klinken, G. 2008. The limits of ethnic clientelism in Indonesia. Review of Indonesian and Malaysian Affairs (RIMA) 42(2): 35-65.

Wasino. 2013. Indonesia: From pluralism to multiculturalism. Paramita: Historical Studies Journal 23(2): 148-155.

2008. Kapitalisme bumi putra: Perubahan masyarakat mangkunegaran. Yogyakarta: LKiS.

2006. Tanah desa dan penguasa: Sejarah pemilikan dan penguasaan tanah di pedesaan Jawa. Semarang, Indonesia: Unnes Press.

Wasino, Hartatik, E.S. and Nawiyanto. 2019. From royal family-based ownership to state business management: Mangkunegara's sugar industry in Java from the middle of the 19th to early 20th century. Management and Organizational History 14(2): $167-183$.

Widyatmadja, Y.P. 2010. Yesus dan wong cilik: Praksis diakonia transformatif dan teologi rakyat di Indonesia. Medan, Indonesia: BPK Gunung Mulia.

Yang, A.J.A. and Samsudin, M. 2017. Polemik aliran sosialis Marxisme dalam gerakan nasionalisme dan pembangunan politik radikal Melayu, 1925-1948. KEMANUSIAAN the Asian Journal of Humanities 24(2): 31-58, https://doi.org/ 10.21315/kajh2017.24.2.2 